\title{
WPEYW EKOINNOWACJI NA WZROST KONKURENCYJNOŚCI PRZEDSIĘBIORSTW
}

Z a r y s t r e ś c i: Ekoinnowacje są jednym ze sposobów osiągnięcia przewagi konkurencyjnej przedsiębiorstwa na rynku. Niniejsze opracowanie ma na celu przybliżenie znaczenia tego pojęcia oraz ukazanie jego wpływu na konkurencyjność. Tekst podzielony został na trzy części, w pierwszej z nich została przedstawiona charakterystyka i podstawowe typologie pojęcia ekoinnowacji. Druga część to zdefiniowanie barier i determinantów wprowadzania tego typu innowacji w przedsiębiorstwie, ostatnia część natomiast to ukazanie powiązań pomiędzy innowacjami ekologicznymi a konkurencyjnością.

S ło w a k 1 u c z o w e: ekoinnowacje; innowacje ekologiczne; konkurencyjność.

\section{WSTĘP}

Zmiany zachodzące w warunkach funkcjonowania współczesnej gospodarki oraz coraz większe skupienie uwagi na problematyce ochrony środowiska wymuszają na przedsiębiorstwach koniczność wdrażania systemów zarządzania środowiskiem oraz różnego rodzaju ekoinnowacji. Ekoinnowacja to odpowiedź na wymagania otoczenia rynkowego, połączenie rozwiązań innowacyjnych z troską o środowisko. W ostatnich latach nieustannie pojawiają się nowe techniki i technologie, a konkurencja stale się nasila. W takiej sytuacji przedsiębiorstwo, które nie wprowadza zmian lub zbyt wolno reaguje na zdarzenia zachodzące w otoczeniu, może upaść.

* Adres do korespondencji: Monika Żółko, Uniwersytet Ekonomiczny w Krakowie, Wydział Ekonomii i Stosunków Międzynarodowych, e-mail: monikaz61@wp.pl; Justyna Mróz, Uniwersytet Ekonomiczny w Krakowie, Wydział Ekonomii i Stosunków Międzynarodowych e-mail: justyna_mroz@yahoo.com. 
Celem artykułu jest przedstawienie, w jaki sposób działania z zakresu innowacyjności mogą przyczynić się do poprawy przewagi konkurencyjnej przedsiębiorstw. Dostosowanie funkcjonowania przedsiębiorstwa w zakresie ochrony środowiska wpływa na działania ekoinnowacyjne, a tym samym w dłuższej perspektywie czasu na poprawę jego konkurencyjności.

\section{CHARAKTERYSTYKA I RODZAJE EKOINNOWACJI}

Innowacje ekologiczne (ekoinnowacje) są zjawiskiem równie złożonym i wielowymiarowym, jak pozostałe rodzaje innowacji. W ujęciu prawnym za innowacje ekologiczne uznaje się wszystkie formy innowacji zmierzające do znacznego i widocznego postępu w kierunku realizacji celu w postaci zrównoważonego rozwoju, m.in. poprzez ograniczenie oddziaływania na środowisko lub osiągnięcia większej skuteczności i odpowiedzialności w zakresie wykorzystania zasobów, w tym również energii [Decyzja nr 1639/2006/WE].

Ekoinnowacja to każda innowacja, która prowadzi do osiągnięcia zrównoważonego rozwoju przez ograniczenie negatywnego oddziaływania działalności produkcyjnej na środowisko naturalne, zwiększenie odporności przyrody na obciążenia lub zapewnienie większej skuteczności i odpowiedzialności w zakresie korzystania z zasobów naturalnych [Komisja Europejska, 2014].

Jedną z pierwszych definicji ekoinnowacji zaproponowali C. Fussler i T. James, którzy określili je jako innowacje, które przynoszą korzyść zarówno przedsiębiorcy, jak i konsumentowi, zmniejszając jednocześnie oddziaływanie na środowisko [Fussler i James, 1996, s. 364]. Innymi słowy, ekoinnowacja może być postrzegana jako każda innowacja zmniejszająca negatywne oddziaływanie procesów gospodarczych na środowisko naturalne oraz zmniejszająca szkody dla środowiska [Kanerva i in., 2009, s. 7]. Z kolei Woźniak i Ziółkowski ekoinnowacje postrzegają jako zmiany, które świadomie dążą do obniżenia obciążeń środowiska. Ich zdaniem jest to swoiste połączenie innowacyjności z wrażliwością na środowisko i świadomością ekologiczną organizacji [Woźniak, Ziółkowski, 2006, s. 21-22]. G. Huppes zaś ekoinnowacje definiuje jako zmiany w sposobie prowadzenia działalności gospodarczej, polegające na włączeniu $\mathrm{w}$ procesy decyzyjne, procesy produkcji oraz pozostałe procesy związane z rozwojem gospodarczym na każdym poziomie analizy z kwestiami społecznymi i dotyczącymi ochrony środowiska [Huppes, i in., 
2010, s. 20]. Ekoinnowacja określana jest także jako proces polegający na rozwoju nowego produktu, w którym przedsiębiorstwo podejmuje świadome działania w celu osiągnięcia wyższego poziomu ochrony środowiska, dążąc jednocześnie do wdrożenia tego produktu na rynek i przez to zwiększenia na nim swoich udziałów [Araszkiewicz, 20012, s. 55].

Termin ekoinnowacja odnosi się do wszystkich form innowacji (technicznych i pozatechnicznych), stwarzających szanse dla przedsiębiorstw oraz przynoszących korzyść środowisku dzięki zapobieganiu negatywnemu wpływowi na środowisko naturalne lub ograniczanie go, również dzięki optymalizacji wykorzystania zasobów naturalnych. Ekoinnowacje są ściśle związane ze sposobem wykorzystania zasobów naturalnych i z rodzajem produkcji i konsumpcji. Sprzyjają one przejęciu przedsiębiorstw produkcyjnych z technologii „końca rury” na rozwiązania zamkniętego obiegu, które minimalizują przepływ materiałów i energii za pomocą zmiany produktów oraz metod produkcji, przynosząc tym samym przewagę konkurencyjną wielu przedsiębiorstwom i sektorom [Komisja Europejska, 2014].

Z punktu widzenia ich przedmiotu można dokonać następującego podziału ekoinnowacji [Podręcznik Oslo, 2008, s.19]:

- ekoinnowacje produktowe - polegające na wprowadzaniu wyrobów lub usług w dziedzinie ekologii, pozwalających na realizację celów ekologicznych, nowe lub znacząco udoskonalone w zakresie swoich celów lub zastosowań. Przykład: zastępowanie środków produkcji materiałami o ulepszonych cechach, np. przyjazne dla środowiska tworzywa sztuczne, wprowadzanie produktów o zdecydowanie zmniejszonym poborze energii, np. energooszczędne lodówki;

- ekoinnowacje procesowe - polegające na wdrażaniu nowej lub znacznie udoskonalonej metody produkcji lub dostawy spełniające kryterium celowości i dziedziny związanej z ochroną środowiska i ekorozwojem. Przykład: instalacja nowej lub ulepszonej technologii produkcji pozwalające ograniczyć negatywne oddziaływanie na środowisko naturalne;

- ekoinnowacje organizacyjne - oznaczają wdrożenie nowej metody organizacyjnej w przyjętych przez przedsiębiorstwo zasadach działania, w organizacji miejsca pracy lub relacji $\mathrm{z}$ otoczeniem, przy jednoczesnym rozwijaniu świadomości ekologicznej i zdolności do realizacji zadań związanych z ekorozwojem i rozwojem zrównoważonym. Przykład: powołanie formalnych lub nieformalnych zespo- 
łów roboczych, realizujących zadania związane z działalnością proekologiczną, wdrożenia systemu zarządzania środowiskowego, np. ISO14000;

- ekoinnowacje marketingowe - polegające na wdrożeniu nowej metody marketingowej związanej ze znacznymi zmianami w projekcie lub konstrukcji produktu/opakowania, dystrybucji, promocji, ze szczególnym uwzględnieniem zasad proekologicznych lub kształtowaniem świadomości ekologicznej w ramach działalności PR. Przykład: wprowadzenie nowego projektu opakowania, uwzględniającego rozwiązania przyjazne środowisku i wykorzystania tego faktu w komunikacji marketingowej.

Interesującą typologię ekoinnowacji przedstawia K. Rennings. Wskazuje on podział na następujące rodzaje innowacji [Rennings, 1998, s. 5-6]:

- ekoinnowacje technologiczne - obejmują produkty i procesy, zwłaszcza technologie (reaktywne, zwane też addytywnymi, technologie „końca rury”; technologie prewencyjne mające charakter zintegrowanych lub ,czystych technologii”, ich celem jest niedopuszczenie do powstania zanieczyszczenia);

- ekoinnowacje społeczne - postrzegane jako konsekwencja przestrzegania wzorców zrównoważonej konsumpcji przez społeczeństwo, obejmują np. nawyki konsumpcyjne, proekologiczne zachowania;

- ekoinnowacje organizacyjne - wynikają z procesów lub technik zarządzania, wyróżniają np. sferę ,zielonych” prac badawczo-rozwojowych czy też obszar ekoaudytów;

- ekoinnowacje instytucjonalne - obejmują organizacje działające na różnych szczeblach i obszarach geograficznych, które w procesie decyzyjnym dążą do uwzględnienia aspektów środowiskowych w kontekście realizacji założeń zrównoważonego rozwoju, nieformalne grupy, platformy współpracy, sieci powoływane w celu zajmowania się kwestiami środowiskowymi.

Ekoinnowacje są pojęciem ewoluującym i ściśle sprzężonym z aktualnym stanem wiedzy $\mathrm{w}$ dziedzinie ochrony środowiska i ekologii, jak również ze specyficznymi celami wyznaczonymi na poziomie organizacji, a także programów i strategii rządowych oraz międzynarodowych wspierających rozwój zrównoważony i ochronę środowiska [Matejun, 2009, s. 22-23].

Wprowadzanie ekoinnowacji w przedsiębiorstwie można rozpatrywać na różnych płaszczyznach, np. pod kątem strategicznym, taktycznym lub operacyjnym. W kontekście rodzajowym mogą mieć one charakter ekono- 
miczny, społeczny, techniczno-produkcyjny i przede wszystkim ekologiczny. Do głównych celów wprowadzania ekoinnowacji w przedsiębiorstwie można zaliczyć [Matejun, 2009, s. 24]:

- zmniejszenie, zapobieganie lub eliminacja negatywnego oddziaływania przedsiębiorstwa na środowisko naturalne;

- wspieranie realizowania przez przedsiębiorstwo strategii zrównoważonego rozwoju;

- poprawę wyniku ekonomicznego sprawności prowadzonej działalności, obniżenie kosztów działalności;

- poprawę wizerunku i reputacji przedsiębiorstwa w otoczeniu oraz w oczach interesariuszy, w tym opinii publicznej i środowisk proekologicznych;

- poprawę bezpieczeństwa i warunków pracy;

- wzrost wartości firmy w ocenie inwestorów.

Kolejnymi elementami procesu zarządzania innowacjami ekologicznymi są następujące narzędzia i instrumenty wykorzystywane w procesie ich wdrażania [Nowak, 2008, s. 301-303]:

- audyt środowiskowy;

- systemy zarzadzania środowiskowego, np. ENAS, ISO14000, program ResponsibleCare;

- ocena oddziaływania na środowisko (EIA);

- narzędzia dokonywania środowiska ekologicznego;

- bilans ekologiczny (ekobilans);

- ekologiczne projektowanie cyklu życia wyrobu (LCD lub DFE);

- środowiskowa ocena miejsc i organizacji (EASO);

- metody wielokryterialnego podejmowania decyzji;

- metody heurystyczne, np. burze mózgów;

- metody modelowania i symulacji.

\section{DETERMINANTY I BARIERY WPROWADZENIA EKOINNOWACJI W PRZEDSIĘBIORSTWIE}

Determinanty działalności ekoinnowacyjnej przedsiębiorstw to zespół czynników o charakterze zewnętrznych (egzogenicznym) oraz wewnętrznym (endogenicznym). Przyczyniają się one do kreowania nowych pomysłów, rozwiązań oraz wynalazków ukierunkowanych na ograniczanie oddziaływania przedsiębiorstwa na środowisko [Kaźmierczak-Piwko, 2012, 
s. 537]. W literaturze przedmiotu wśród czynników zewnętrznych wpływających na tworzenie ekoinnowacji wyróżnić możemy konkurencję, oczekiwania konsumentów, regulacje prawne z zakresu ochrony środowiska, osiągnięcia nauki i techniki, postęp ekonomiczno-społeczny oraz zmiany w otoczeniu [Drucker, 1992, s. 37]. Czynniki wewnętrzne natomiast, które są znacznie rzadziej rozważane w literaturze przedmiotu, to między innymi: ,świadomość ekologiczna i aspiracje menedżerów, dobrowolne zobowiązania, polityka środowiskowa przedsiębiorstwa, strategia konkurencji, a więc wszystkie czynniki wpływające na funkcjonowanie w danym przedsiębiorstwie systemu zarządzania" [Graczyk, Kaźmierczak-Piwko, 2011, s. 110].

W literaturze przedmiotu występują różnego rodzaju ujęcia i typologie czynników determinujących wprowadzanie ekoinnowacji. Przykładowo Vanessa Oltra wyróżnia w tym obszarze trzy następujące kategorie: czynniki prawno-polityczne, czynniki podażowe oraz czynniki popytowe [Ryszko, 2014, s. 128]. Według J. Horbacha natomiast w strukturze determinantów ekoinnowacji należy wyróżnić cztery grupy, takie jak:

- czynniki związane ze specyfiką danego przedsiębiorstwa;

- czynniki związane z tak zwanym efektem „tłoczenia technologii” (technology push);

- czynniki związane z tak zwanym efektem „ssania rynku” (market pull);

- aktualne i przewidywane regulacje ochrony środowiska.

Przyczyny podejmowania inwestycji proekologicznych wymienia także w swoim opracowaniu M. Kożuch, zestawiając je w czterech grupach [Kożuch, 2012, s. 335]:

- uwarunkowania prawne - instrumenty bezpośredniego oddziaływania na zachowania proekologiczne przedsiębiorców;

- uwarunkowania techniczne - nowoczesne, oszczędne rozwiązania technologiczne i techniczne;

- mikroekonomiczny rachunek opłacalności inwestycji - porównanie kosztów emisji zanieczyszczeń z kosztami redukcji emisji (przedstawione szczegółowo na rysunku 1);

- kreowanie „ekologicznego” wizerunku przedsiębiorstw. 


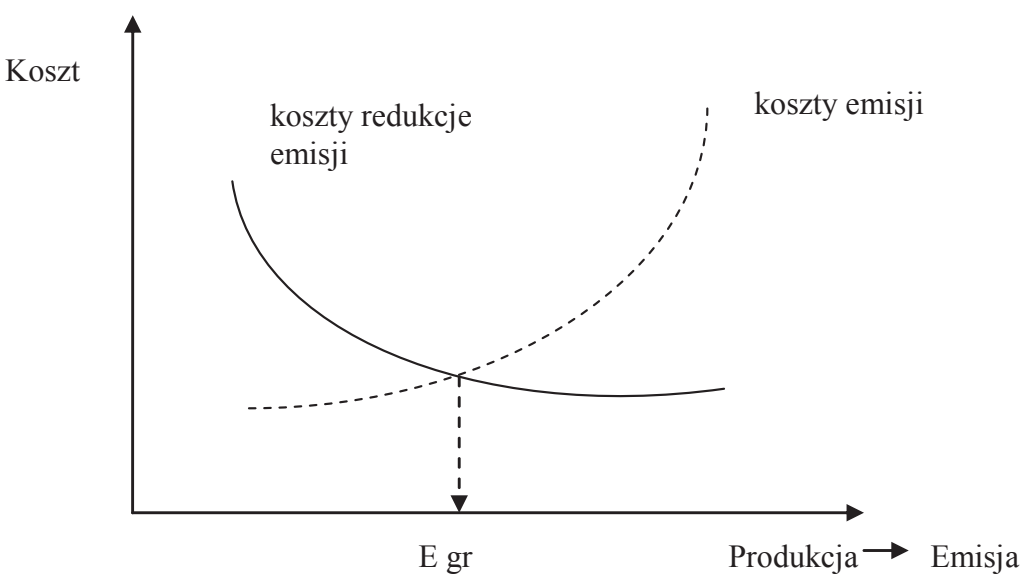

Rysunek 1. Mikroekonomiczny rachunek opłacalności inwestycji proekologicznych w przedsiębiorstwie

Źródło: E. Broniewicz, Badanie opłacalności przedsięwzięć z zakresu ochrony środowiska, [w:] B. Poskrobko (red.), Zarzadzanie ochrona środowiska w przedsiębiorstwie i gminie, Wydawnictwo Polskie Zrzeszenie Inżynierów i Techników Sanitarnych w Poznaniu, Poznań-Białystok 1997, s. 192.

W literaturze ważne miejsce zajmuje także problem barier wprowadzania ekoinnowacji w przedsiębiorstwach. Wśród nich wyszczególnić można [Ryszko, 2014, s. 129-130]:

- bariery prawne (przykładowo niejasne i nieprzejrzyste przepisy, nieprzewidywalne zmiany przepisów powodujące niepewność rynku i zniechęcające do inwestowania, nieprawidłowo ustalone standardy);

- bariery ekonomiczne (przykładowo brak środków finansowych $\mathrm{w}$ przedsiębiorstwie, brak finansowania zewnętrznego, wysokie koszty procesu innowacyjnego, duże ryzyko i niepewny zwrot inwestycji);

- bariery popytowe (przykładowo niepewny popyt na rynku, rynek zdominowany przez istniejące przedsiębiorstwa, wypaczanie rynku interwencjonizmem w postaci subsydiów do rozwiązań uciążliwych dla środowiska, brak możliwości wyróżnienia produktu pod względem jego ekologicznej preferencyjności w związku z deficytem wiarygodnej informacji); 
- bariery technologiczne (przykładowo potencjał technologiczny, ograniczona dostępność technologii, przestarzała infrastruktura hamująca rozwoj gospodarki);

- bariery sfery badawczo-rozwojowej (przykładowo niedostosowanie działalności instytucji naukowo-badawczych do potrzeb innowacyjnych, niedostateczne finansowanie projektów badawczo-rozwojowych, brak wsparcia współpracy między nauką a przemysłem);

- bariery kadrowe (przykładowo brak doświadczonego i wykwalifikowanego personelu, brak odpowiednich umiejętności menedżerskich i wiedzy technicznej, brak zdolności do zarządzania zadaniami związanymi z procesem ekoinnowacyjnym, niechęć do zmian, brak zdolności absorbowania rozwiązań opracowanych poza przedsiębiorstwem);

- bariery współpracy (przykładowo brak odpowiednich dostawców, partnerów biznesowych, niedostateczna współpraca przedsiębiorstw z instytucjami naukowo-badawczymi, ograniczony dostęp do zewnętrznych informacji i wiedzy).

\section{INNOWACJE PROEKOLOGICZNE A KONKURENCYJNOŚĆ PRZEDSIĘBIORSTW}

Pozytywny wpływ ekoinnowacji na działalność przedsiębiorstwa został szeroko scharakteryzowany w publikacji B. Ziółkowskiego, który za punkt wyjścia swoich rozważań przyjął negatywny aspekt oddziaływania na środowisko. Jego eliminacja lub zminimalizowanie możliwe jest dzięki wprowadzaniu ekoinnowacyjnych technologii, przyczyniających się do zmniejszenia tego oddziaływania. Pozwala to przedsiębiorstwu na ponoszenie mniejszych opłat środowiskowych oraz ewentualnych kar, jak również zredukowanie kosztów pozyskiwania wyczerpujących się zasobów naturalnych i uniezależnienie się od tradycyjnych źródeł energii. W ten sposób ekoinnowacje pozytywnie wpływają na zdolność inwestycyjną przedsiębiorstwa. Mimo że ich wprowadzenie początkowo związane jest ze znaczącymi inwestycjami oraz barierami w rozwoju, większość specjalistów pokłada w nich duże szanse dla rozwoju zwłaszcza małych i średnich przedsiębiorstw [Ziółkowski, 2008, s. 8]. W literaturze wskazuje się także duże szanse na promocję w Europie, ponieważ ubieganie się o wsparcie dla ekoinnowacyjnych rozwiązań w ramach programów unijnych może być doskonałą szansą dla sektora MŚP w zakresie nawiązywania współpra- 
cy międzynarodowej, promocji firmy w Europie, jak również budowania świadomości marki [Foltynowicz, 2009].

Bardzo ważnym elementem we wprowadzaniu ekoinnowacji są zmiany zachodzące w świadomości społecznej, polegające na akceptacji czystego środowiska jako element dobrobytu społecznego. Przedsiębiorstwo może budować swoją przewagę konkurencyjną między innymi poprzez zróżnicowanie produktu oraz respektowanie ekologicznych preferencji potencjalnych grup konsumentów [Żaba-Nieroda, 2011, s. 177]. Sprostanie ekologicznym gustom odbiorców może się przekładać na konkurencyjność produktów przedsiębiorstwa, a tym samym prowadzić do wzrostu popytu na oferowane przez przedsiębiorstwo produkty, co równoznaczne jest ze zwiększeniem przychodów i umocnieniem pozycji na rynku. Produktami takimi mogą być np. energia odnawialna, czysta energia, spełnienie norm środowiskowych itp. Przewaga konkurencyjna osiągnięta w wyniku wdrażania działań i zachowań proekologicznych ma znaczenie w poprawie konkurencyjności tylko w przypadku gdy [Burzyńska, Fila, 2007, s. 56]:

- zostaną stworzone odpowiednie warunki oraz sposoby liczenia i internalizacji kosztów zewnętrznych;

- zostaną stworzone warunki do powszechnego i skutecznego egzekwowania zobowiązań wykorzystania środowiska;

- nastąpi wzrost świadomości ekologicznej społeczeństwa połączony ze zmianą wzorców konsumpcyjnych i preferencji konsumenta.

Ekoinnowacje stanowią jedną z głównych zdolności wyróżniających przedsiębiorstwo wśród konkurencji i mogą być stałym źródłem przewagi na rynku. Obowiązek przestrzegania standardów środowiskowych wymusza na przedsiębiorstwach większą otwartość na postęp techniczny $i$ innowacyjność. W krajach wysokorozwiniętych od wielu lat widoczny jest coraz większy spadek udziału w rynku przedsiębiorstw przemysłowych, funkcjonujących zarówno w przemyśle tradycyjnym, jak również w sektorach zaliczanych do przemysłu wysokiej techniki, które jeszcze w latach 70. należały do najdynamiczniej rozwijających się w przemyśle światowym. Uaktywniły się zaś przedsiębiorstwa świadczące usługi w zakresie organizacji czasu wolnego, usługi biznesowe i pośrednictwo finansowe, związane z ochroną zdrowia, ochroną środowiska oraz technologiami informacyjnymi i zapleczem badawczo-rozwojowym. Wspólną cechą współczesnych przedsiębiorstw jest poszukiwanie i wykorzystywanie innowacyjności w celu przyspieszenia rozwoju i uzyskania przewagi konkurencyjnej i umocnienia swoje przewagi na rynku. Wprowadzanie innowacyjnych rozwiązań przyczynia się również do poprawy wydajności pracy oraz rentow- 
ności przedsiębiorstwa, jak również do ograniczenia ekologicznych kosztów zewnętrznych. Przedsiębiorcy w procesach decyzyjnych coraz częściej decydują się uwzględniać założenia rozwoju trwałego i zrównoważonego, celem którego jest nie tylko zapobieganie degradacji środowiska przyrodniczego, ale również zachowanie przezorności ekologicznej, wyrażającej się redukcją emisji zanieczyszczeń w stopniu wynikającym ze stosowania nowych technologii [Kożuch, 2012, s. 339].

\section{PODSUMOWANIE}

Przedsiębiorstwa podejmują się działalności ekoinnowacyjnej z bardzo wielu powodów. Ich cele mogą dotyczyć produktów, rynków, efektywności, jakości i wdrażania zmian. Identyfikacja motywacji do podjęcia działalności innowacyjnej oraz roli tych motywów zdecydowanie ułatwia zbadanie czynników stymulujących działalność innowacyjną, takich jak wejście na nowe rynki czy konkurencja.

Ekoinnowacyjność może stanowić fundament zachowań konkurencyjnych przedsiębiorstwa. Jest bowiem elementem składowym potencjału organizacji, tym samym staje się podstawą do budowania przewagi na współczesnym rynku globalnym. Ograniczanie emisji gazów cieplarnianych, zużycia energii, wykorzystanie odnawialnych źródeł energii oraz surowców biodegradowalnych, ograniczenie lub całkowita eliminacja syntetycznych barwników i konserwantów dodawanych do produktów żywnościowych to niezbędne wyznaczniki oferty współczesnych przedsiębiorstw. Ekoinnowacjami zainteresowani są przede wszystkim konsumenci, którzy dzięki akcjom informacyjnym posiadają coraz większą wiedzę, wrażliwość ekologiczną i świadomość konieczności wprowadzania fundamentalnych zmian w produktach i usługach. Tożsame oczekiwania mają także odbiorcy instytucjonalni. Poszukują oni takich technologii produkcji, które pozwolą spełnić restrykcyjne wymagania przepisów o ochronie środowiska. Dzięki nowoczesnym rozwiązaniom oczekują oni także efektu ekonomicznego, wynikającego np. z redukcji zapotrzebowania na energię czy też redukcji odpadów produkcyjnych. 


\section{LITERATURA}

Araszkiewicz K., (2012), Innowacje ekologiczne a konkurencyjność gospodarki regionu, praca doktorska, Wydział Zarządzania, Uniwersytet Ekonomiczny w Poznaniu, Poznań.

Broniewicz E., (1997), Badanie opłacalności przedsięwzięć z zakresu ochrony środowiska [w:] B. Poskrobko (red.), Zarzadzanie ochrona środowiska w przedsiębiorstwie i gminie, Wydawnictwo Polskie Zrzeszenie Inżynierów i Techników Sanitarnych w Poznaniu, Poznań-Białystok.

Burzyńska D., Fila J., (2007), Finansowanie inwestycji ekologicznych w przedsiębiorstwie, Difin, Warszawa.

Decyzja nr 1639/2006/WE Parlamentu Europejskiego i Rady z dnia 24 października 2006 r. ustanawiająca Program ramowy na rzecz konkurencyjności innowacji (2007-2013), Dziennik Urzędowy Unii Europejskiej, L310/15.

Drucker P.F., (1992), Innowacje i przedsiębiorczość. Praktyka i zasady, PWE, Warszawa.

Foltynowicz Z., (2009), Ekoinnowacje szansa na rozwój, Ecomenager, nr 2009-1, Uniwersytet Ekonomiczny w Poznaniu, Poznań.

Fussler C., James T., (1996), Eco-innovation: A Breakthrough Discipline for Innovation and Sustainability, Pitman Publishing, Londyn.

Graczyk M., Kaźmierczak-Piwko L., (2011), Uwarunkowanie dla tworzenia wiedzy i innowacji ekologicznych w przedsiębiorstwie, Studia i Materiały Polskiego Stowarzyszenia Zarządzania Wiedzą, Bydgoszcz.

Huppes G., Klejn R., Huele R., Ekins P., Shaw B., Schaltegger S., Esders M., (2010), Measuringeco- innovation: Framework and typology ofindicators. Management summaryofthefinal report ofthe ECODRIVE project.

Kanerva M., Arundel A., Kemp R., (2009), Environmentalinnovation: Using qualitativemodels to identifyindicator for policy, United Nations UniversityWorkingPapers Series, Maastricht.

Kaźmierczak-Piwko L., (2012), Determinanty działalności ekoinnowacyjnej przedsiębiorstw, Zarządzanie i Finanse, R. 10, nr 1, cz. 2, Uniwersytet Zielonogórski, Zielona Góra.

Komisja Europejska, Ekoinnowacje, klucz do przyszłejkonkurencji Europy, http:// ec.europa.eu/environment/pubs/pdf/factsheets/ecoinnovation/pl.pdf

Kożuch M., (2012), Inwestycje ekologiczne a konkurencyjność przedsiębiorstw, Studia i Prace Wydziału Nauk Ekonomicznych i Zarządzania, nr 25, Uniwersytet Ekonomiczny w Krakowie, Kraków.

Matejun M., (2009), Zarządzanie innowacjami ekologicznymi we wspótczesnym przedsiębiorstwie, [w:] R. Grądzki, M. Matejun (red.), Rozwój zrówno- 
ważony - zarzadzanie innowacjami ekologicznymi, Wydawnictwo Media Press, Katedra Podstaw Techniki i Ekologii Przemysłowej, PŁ, Łódź.

Nowak J.J., (2008), Zarzadzanie ekologiczne w organizacji [w:] W. Kowalczewski, W. Matwiejczuk (red.), Aktualne problemy zarzadzania organizacjami, Difin, Warszawa.

Podręcznik Oslo, (2008), Zasady gromadzenia i interpretacji danych dotyczacych innowacji, OECD, Eurostat, Wydanie trzecie - polskie, MNiSW, Warszawa.

Ryszko A., (2014), Motywacje i bariery działalności ekoinnowacyjnej przedsiębiorstw w Polsce, Modern Management Review, 21 (1/2014), Politechnika Rzeszowska, Rzeszów.

Wożniak L., Ziółkowski B., (2006), Paradygmat ekonomii ekologicznej jako stymulator ekoinnowacyjności [w:] L. Woźniak, J. Krupa, J. Grzesik (red.), Innowacje ekologiczne w rozwoju spoteczno-gospodarczym, Wydawnictwo Wyższej Szkoły Informatyki i Zarządzania, Rzeszów.

Ziółkowski B., (2008), Znaczenie ekoinnowacji dla rozwoju przedsiębiorstw [w:] Zrównoważony rozwój w teorii ekonomii i w praktyce, Prace Naukowe AE nr 1190, AE Wrocław.

Żaba-Nieroda R., (2011), Ekoinnowacyjność źródtem przewagi konkurencyjnej przedsiębiorstw na przykladzie wybranych elektrowni, Zeszyty Naukowe MWSE w Tarnowie, 2001, nr 2(19), Ochrona środowiska, Tarnów.

\title{
ECO-INNOVATIONS IMPACT ON THE GROWTH OF COMPETITIVENESS OF ENTERPRISES
}

\begin{abstract}
A bstract: Eco-innovations are one of the way businesses achieve a competitive advantage in the market. This paper aims to bring its meaning and to show its impact on competitiveness. The text is divided into three parts, the first of which was presented characteristics and basic concepts of eco-innovation typologies. The second part is to define the barriers and determinants of introducing this kind of innovation in the enterprise, while the last part is to show the links between ecoinnovation and competitiveness.
\end{abstract}

K e y w o r d s: eco-innovation; competitiveness; innovation 